\title{
Rainfall Partitioning for Integrated Water Resources Management: Case Study of Upper Blue Nile Basin, Ethiopia
}

\author{
Mastewal Ejigu Ademe \\ Water Management, Bahir Dar University, P.O. Box 3062, Silver Spring, Maryland 20918, USA
}

\begin{abstract}
The Upper Blue Nile Basin, the highest sources of the Nile River flow through this area, is still under severe land degradation, which aggravates water scarcity. The productivity of subsistence farming is below $50 \%$ of the potential of agriculture, mainly because of inappropriate rainwater management. At farm level, rainwater is exposed to poor partitioning described as flooding, land degradation, siltation and water scarcity for domestic, irrigation, hydropower and environmental uses in the basin. Hence, it is one of the root causes of food-insecurity in the region. To reverse this situation and achieve increased rainwater productivity knowledge of rainfall partitioning at grassroots level is significantly important. However, rainwater partitioning and partitioning points are not clearly known by farmers in the area. Besides, understanding water-routes helps to manage rainwater with integrated water resources management (IWRM) processes. The objective of this study was to identify the knowledge gap of farmers and experts on rainwater partitioning that help for increased water productivity. Intensive monitoring and interviews have been carried out for 81 farmers and 22 local experts in three pilot sites. The interviewed farmers and experts are clearly aware of the runoff partitioning, since it is easily observable. While, only $10 \%$ of the farmers and $25 \%$ of experts know about evaporation partitioning, which is the largest compared to other losses. The paper gives recommendations for better understanding of rainfall partitioning points and management of water-routes at grassroots level to increase rainwater productivity and enhance food security in the area with IWRM processes.
\end{abstract}

Key words: Blue Nile, knowledge, rainfall partitioning, water loss, water-routes.

\section{Introduction}

Food crisis is the major problem in the horn of Africa, including Ethiopia. The Ethiopian plateau generates about $85 \%$ of Nile waters. The Upper Blue Nile Basin (UBNB) is largely located in the Amhara region of Ethiopia. The people of Amhara region is predominantly an agrarian society, where about $89 \%$ of the population resides in the rural areas. In this region, rain-fed agriculture is practiced by subsistence farmers with traditional approaches. The UBNB has considerable elevation variability. It ranges from 490 meter above sea level (masl) at the Sudan border up to 4,230 masl at the peak of Mount Guna in South Gondar province. The mean daily minimum and

Corresponding author: Mastewal Ejigu Ademe, M.Sc., research field: water resources management. maximum temperatures of the basin is $18.4{ }^{\circ} \mathrm{C}$ and $25.5^{\circ} \mathrm{C}$, respectively [1]. Average annual potential evapo-transpiration is about $1,310 \mathrm{~mm}$. The study area is characterized by high population pressure, rugged topography and land degradation.

Rainfall is the main source of water for agriculture as it is depicted on the three study sites (Figs. 1a and 1b). Water scarcity in the root zone is a major limiting factor for high crop productivity when rain-fed crop-production is compared to irrigation (Fig. 2). If runoff and evaporation losses are regulated, the soil becomes the largest water storage media as in green water form. Worldwide, about $80 \%$ of the agricultural land is rain-fed, producing about $60 \%$ of the world food [2]. It has been recognized that the temporal stability of soil water content patterns in rain-fed systems have profound implications 


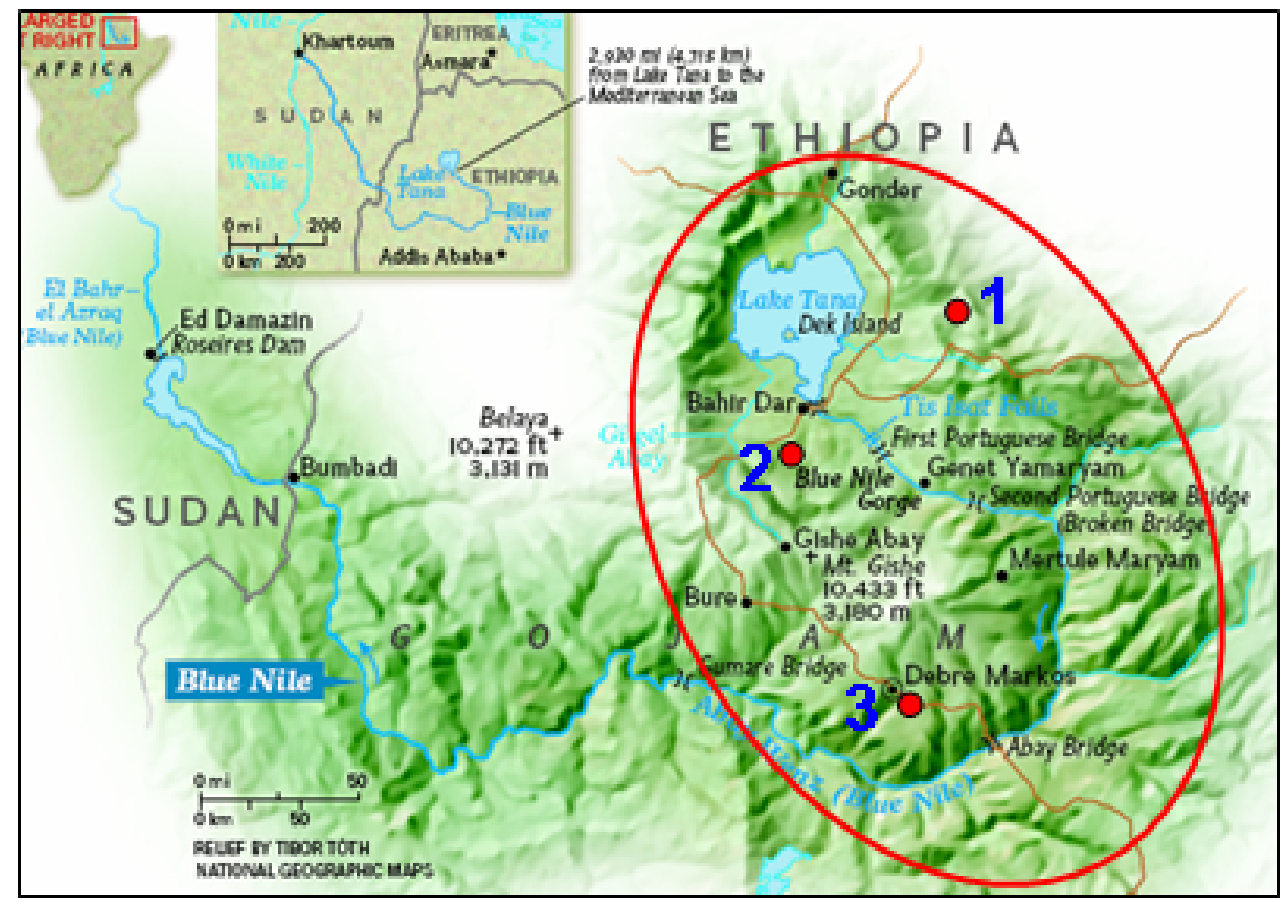

(a)

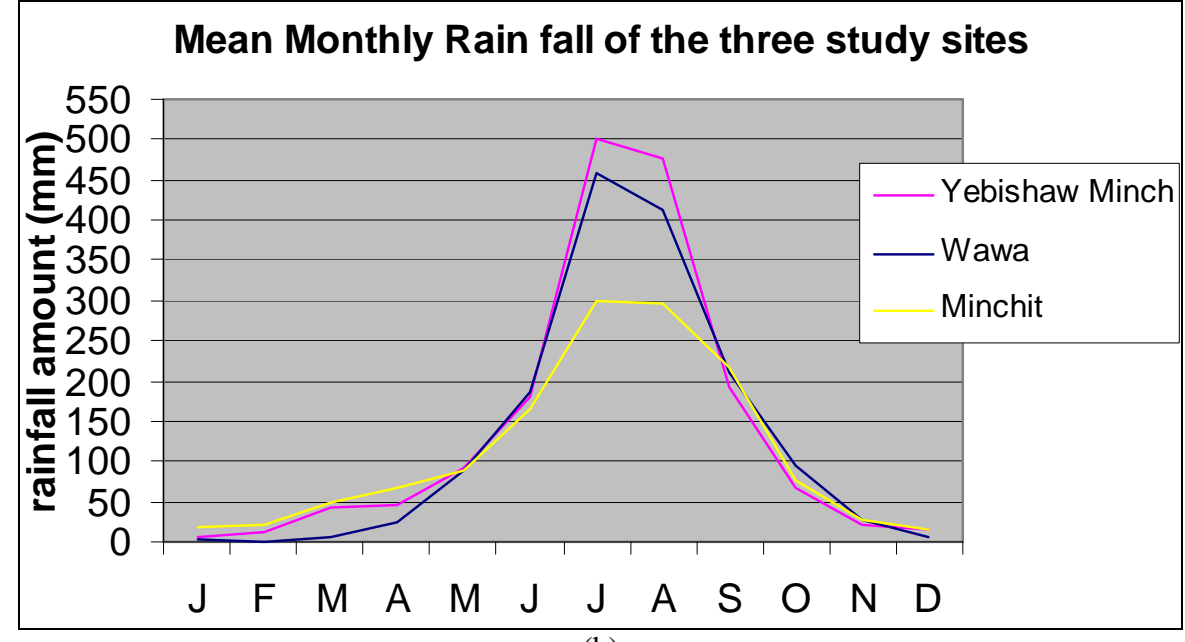

(b)

Fig. 1 Location map of study sites in UBNB with mean monthly rainfall of the corresponding three study sites. 1 = Farta, 2 = Mecha, 3 = Gozamn districts having Yebishaw Minch, Wawa and Minchit watersheds, respectively.

for agriculture in general and water management in particular [3].

Generally at farm level, rainwater is exposed to poor partitioning described as flooding, land degradation and siltation, and results in water scarcity for domestic, irrigation, hydropower and environmental uses in the basin. As an opportunity, rain is the main source of water for all uses. In line to this increasing, water productivity through more effective use of rainfall is an important strategy from economic and environmental point of view [4]. To make the strategy effective, rainfall partitioning should be clearly known to farmers and experts for IWRM process implementation. Thus, the objective of the study is to understand the awareness level of farmers and experts to rainfall partitioning, with specific objective identifying the possible partitioning points and water-routes till spring flow. 


\section{Crop Water Productivity}

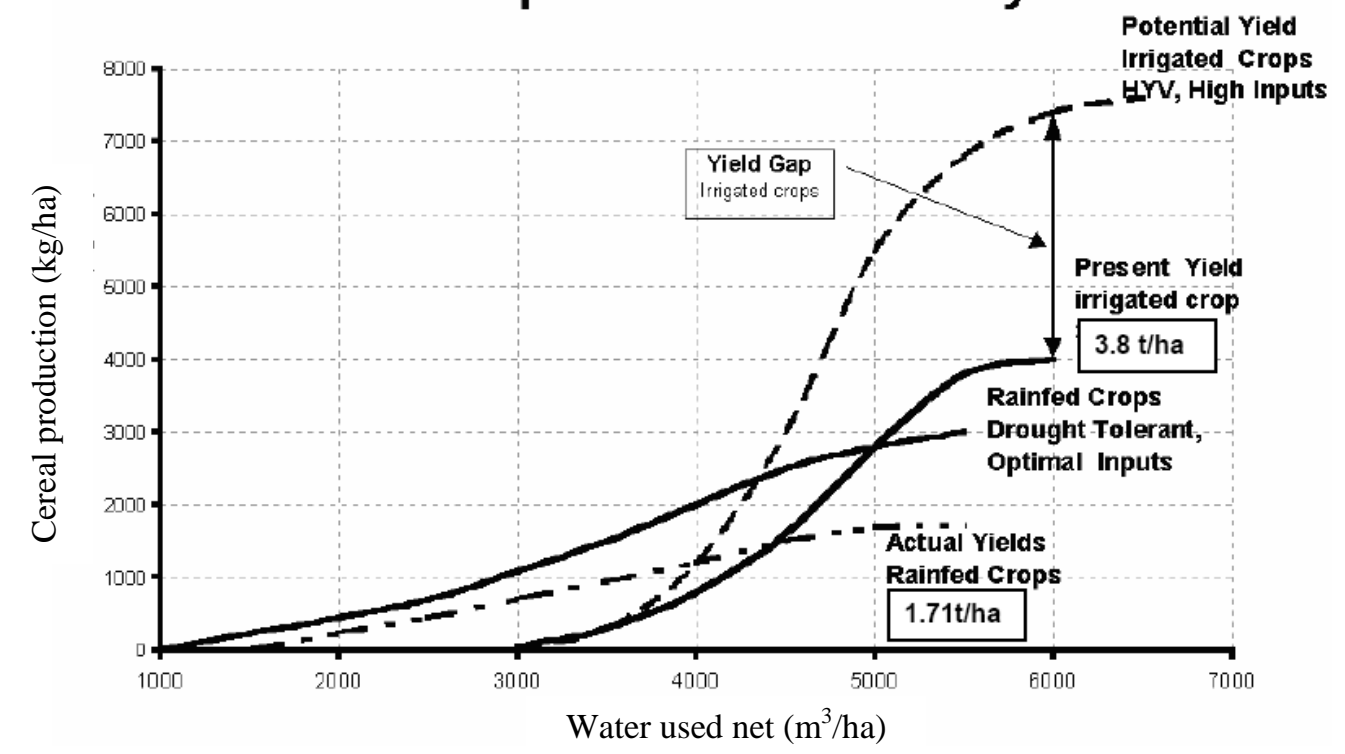

Fig. 2 Crop water productivity under irrigation and rain-fed agriculture [5].

\section{Methodology}

The study was conducted in three sites located in (1) Farta, (2) Mecha and (3) Gozamn districts of Amhara region in the UBNB (Fig. 1a). Each of three sites has four slope ranges of $0-5 \%, 5 \%-15 \%, 15 \%-30 \%$ and > $30 \%$. All sites have equal land size which is 100 ha. Districts have average annual rainfall of about 1,651, 1,521 and 1,341 $\mathrm{mm}$, respectively. With local language "Minch" means spring, though these days in all sites do not have springs unlike before three decade years.

Major data collected include mean monthly rainfall, measurements of soil-moisture content and indigenous rainwater management techniques. Interviews were conducted with farmers, regional relevant experts, district staff and development agents for each study sites. It has been carried out for 81 farmers and 22 experts. Totally 103 persons were interviewed. Further, the result was validated with group discussions. A detailed monitoring using soil moisture level at different agricultural practices was conducted at three study sites in UBNB. Since water is complex by its nature conceptual frame work (CFW), it is configured to fix boundary conditions as shown in Fig. 3 .
A participatory rural appraisal techniques as well as formal individual interviews using a semi-structured questionnaire were undertaken. In-depth interviews were conducted for farmers working within the study sites. In each study site, three farmers including a chairperson were interviewed to get information of the actual water management practices. Two group discussions were employed in each study site using checklist of discussion points with representative farmers, including leaders of the village. A group of about 12 farmers were participated in each of the group discussion.

\section{Results and Discussion}

The study sites Farta, Mecha and Gozamn districts have average annual rainfall of about 1,651, 1,521 and $1,341 \mathrm{~mm}$, respectively, according to metrological data of the region. The main rainy season "meher" normally lasts from June to September. According to local information and metrological data, there is few rain showers used for dry season cropping "belg”. The average monthly rainfall over the three study sites showed excess runoff during the months of June, July, August and September (Fig. 1). The soil depth at Farta district is from medium to shallow depths, in Mecha 
district, it is very deep and at Gozamn district, varies from shallow to very deep as it was investigated during the study.

Here, knowledge level of experts to guide farmers is significantly important to balance the available rainwater during rainy season to the whole year, particularly during dry season. This innovative way of intervention has huge impact on water use equity, economic efficiency and environmental integrity [6]. A number of indigenous water management practices were identified. Their importance with regard to managing rainfall is discussed.

As part of the interview, farmers and experts were asked to express the rainfall partitioning in a year. Surprisingly, their answers to partitioning are quite different from hydrological estimates. They are clearly aware of the runoff partitioning, though not fully regulated (Fig. 4). While, only $10 \%$ of the farmers and $25 \%$ of experts know about evaporation partitioning, which is the largest compared to other water-routes. However, transpiration and deep-percolation are not clearly known to farmers (for $90 \%$ of the population) and few of experts are aware of them (Fig. 4). Whereas partitioning points are new concepts to them.

The region's primary water source is not in the form of river flow rather it is a free fall from sky in the form of rain shower. This free fall of rainwater is subjected to different forms of loss. The major water losses are runoff and evaporation. The major human intervenes in the two partitioning points are farmers who manage their soils and crops [7], hence reducing evaporation loss is one major aspect to increase water productivity. Evaporation can be transformed into useful transpiration, thus contributing to increased water productivity [8].

The result clearly illustrates that there is low familiarity to rainwater partitioning points and water-routes, which has direct correlation with inefficient role for IWRM process at grassroots level, because knowledge of partitioning is one of the critical factors for effective rainwater management at grassroots level. Hence, the primary water resource, freefall of rainwater is subjected to different forms of loss. The major ones are runoff and evaporation. Detail explanation about water-routes is demonstrated by using the water balance as Eq. (1):

$$
\mathrm{P}=\mathrm{Q}_{\mathrm{s}}+\mathrm{E}+\mathrm{T}+\mathrm{D}
$$

where, $\mathrm{P}=$ precipitation, $\mathrm{Q}_{\mathrm{s}}=$ runoff, $\mathrm{E}=$ evaporation, $\mathrm{T}=$ transpiration, $\mathrm{D}=$ deep percolation.

This water balance equation is to sum up all water routes throughout the year. The study area is having hilly topography under completely different two major

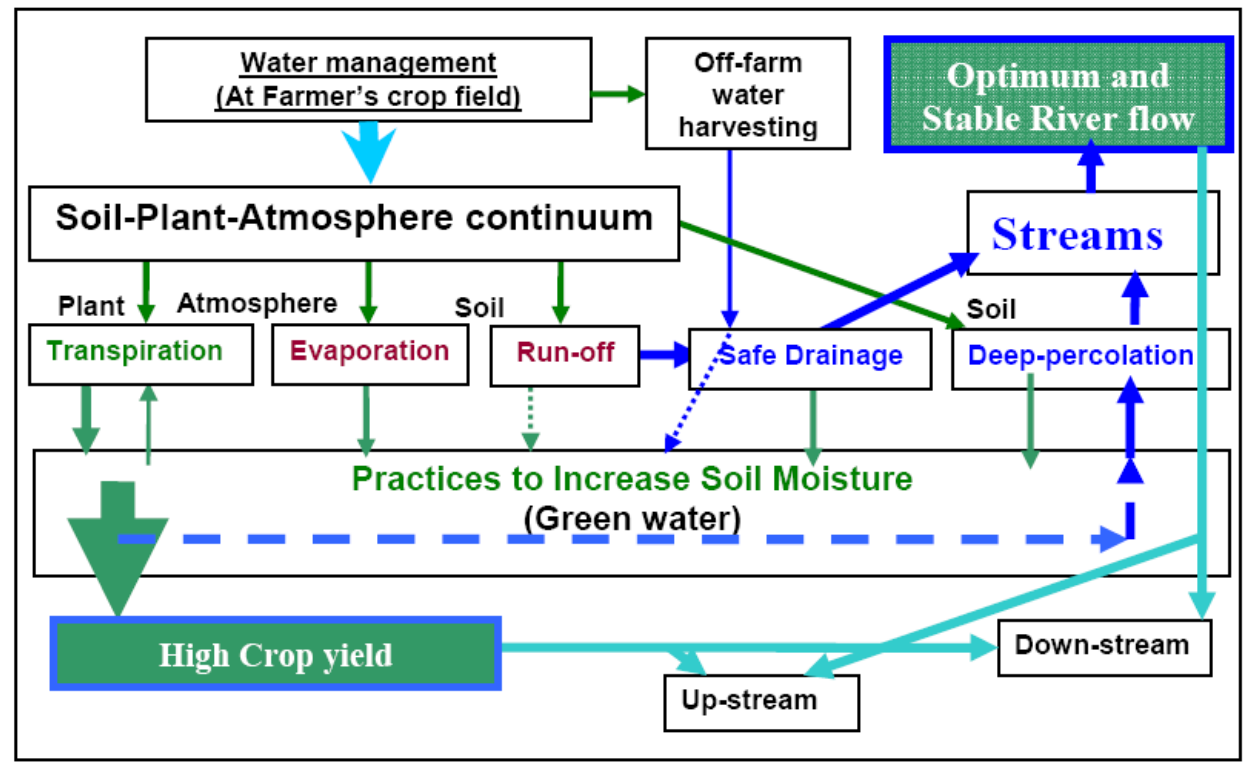

Fig. 3 CFW to increase water productivity at farmer's crop field. 


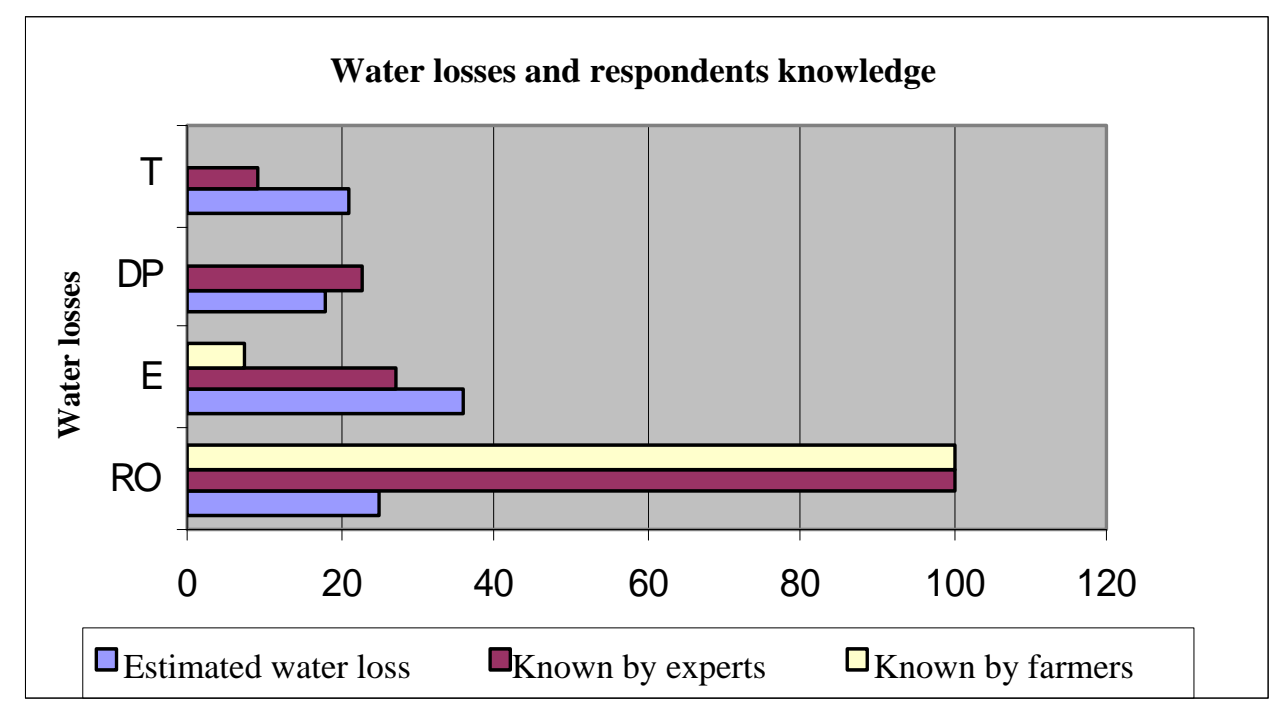

Fig. 4 Estimated water partitioning known to respondents in percent.

$\mathrm{RO}=$ runoff, $\mathrm{E}=$ evaporation, $\mathrm{DP}=$ deep percolation, $\mathrm{T}=$ transpiration.

seasons (dry and rainy seasons) in regard to water availability. Hence, there is variation of spatial and temporal rainfall partitioning and water-routes that are flowing, transpired or evaporating. According to the study, five rainfall partitioning points and 13 water-routes are identified in UBNB.

The new water balance equation for Nile River Basin for all seasons throughout the year is shown in Eqs. (2) and (3):

$$
\begin{aligned}
& \mathrm{P}=\mathrm{Q}_{\mathrm{s}}+\mathrm{E}_{\mathrm{r}}+\mathrm{T}_{\mathrm{r}}+\mathrm{G}_{\mathrm{a}}+\mathrm{T}_{\mathrm{d}}+\mathrm{E}_{\mathrm{d}}+\mathrm{R}_{\mathrm{f}}+\mathrm{E}_{\mathrm{o}}+\mathrm{I}_{\mathrm{e}} \\
& \mathrm{P}=\mathrm{R}_{1}+\mathrm{R}_{3}+\mathrm{R}_{4}+\mathrm{R}_{6}+\mathrm{R}_{8}+\mathrm{R}_{9}+\mathrm{R}_{11}+\mathrm{R}_{12}+\mathrm{R}_{13}
\end{aligned}
$$$$
\text { where, } \mathrm{P}=\text { precipitation; }
$$

$\mathrm{E}_{\mathrm{r}}=$ evaporation during rainy season $\left(\mathrm{R}_{1}\right)$;

$\mathrm{Q}_{\mathrm{s}}=\operatorname{runoff}\left(\mathrm{R}_{3}\right)$;

$\mathrm{T}_{\mathrm{r}}=$ transpiration during rainy season $\left(\mathrm{R}_{4}\right)$;

$\mathrm{G}_{\mathrm{a}}=$ ground water abstraction $\left(\mathrm{R}_{6}\right)$;

$\mathrm{T}_{\mathrm{d}}=$ transpiration during dry season $\left(\mathrm{R}_{8}\right)$;

$\mathrm{E}_{\mathrm{d}}=$ evaporation during dry season $\left(\mathrm{R}_{\mathrm{g}}\right)$;

$I_{e}=$ infiltration for the environment $\left(R_{11}\right)$;

$\mathrm{E}_{\mathrm{o}}=$ evaporation on open water surface $\left(\mathrm{R}_{12}\right)$;

$\mathrm{R}_{\mathrm{f}}=$ river flow $\left(\mathrm{R}_{13}\right)$.

In Ethiopia, the first two partitioning points are crucially important for soil-water management, in other words for optimized green-water management [9]. But largely the deep percolated water is further subjected to another three partitioning points (Fig. 5).
Then in UBNB, farmers' must influence the 1st, 2nd, 3rd and 4th partitioning points and thereby the 5th partitioning point which determines spring flows that feeds cumulatively the Nile River.

To minimize the effect of direct sun light and reduce evaporation, the farmers use different indigenous water management practices, including post-harvest tillage (PHT), residual moisture use (RMU) and back-yard farming (BYF), relay cropping and traditional agro-forestry. However, most farmers are not aware of evaporation control, even though they adopted traditional experiences starting from old ages and humbly understood the benefits of their techniques in terms of better crop yield harvested and ease of soil workability. Similarly runoff water loss is believed as it is nature's normal process, and they do not fully understand as it could be well managed and controlled. These significantly describe that even though farmers construct soil and water conservation measures and use traditional rainwater management techniques to increase crop yield, they do not fully understood the rainfall partitioning on their farmland. In other words, despite there is enough rainwater resource in the region, rainfall partitioning and water-routes are not clearly known by the majority of the farming community for better rainwater management 

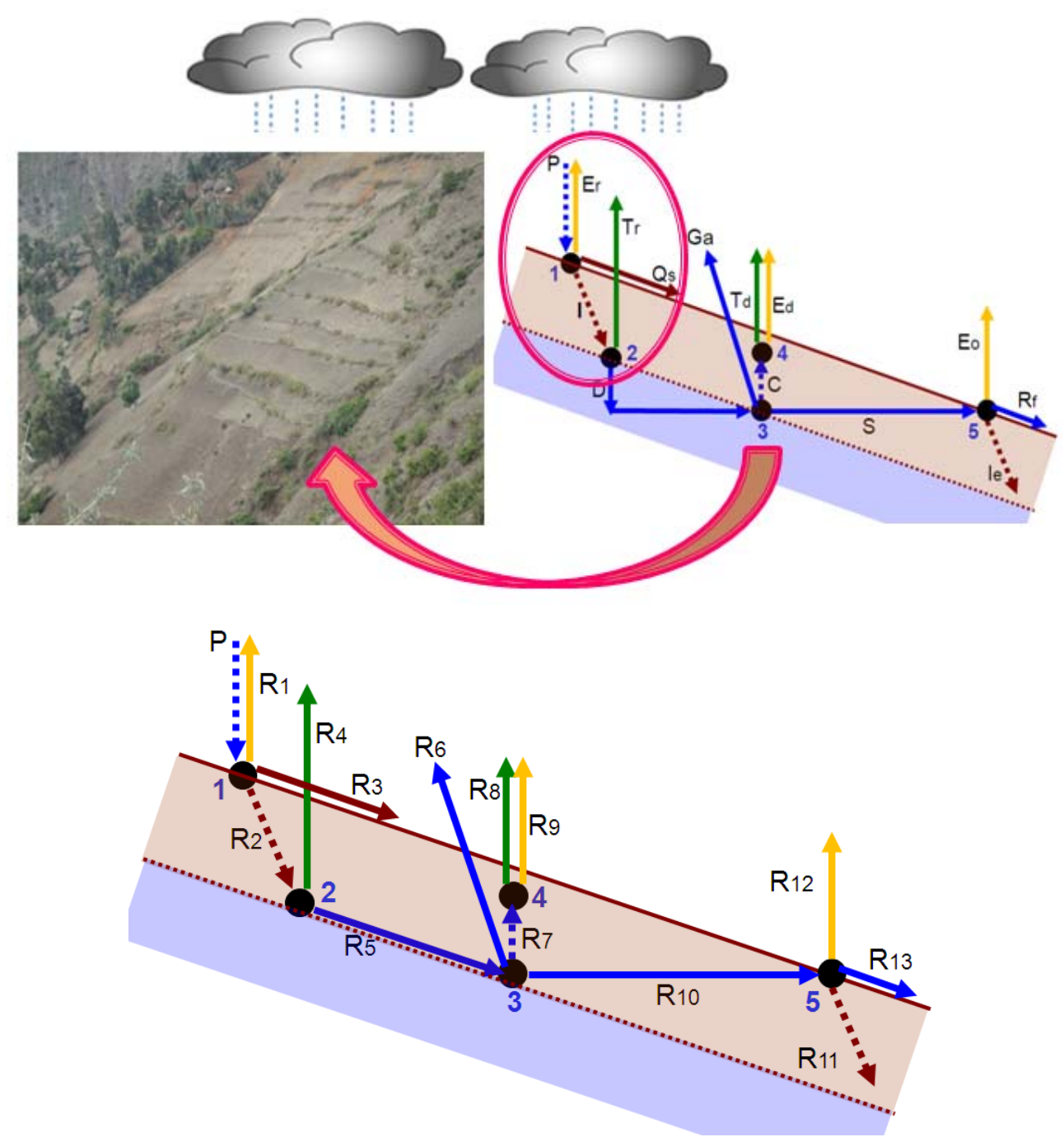

Fig. 5 Spatial and temporal rainfall of five partitioning points and 13 water-routes in UBNB.

targets. This is the root cause of poverty, because it significantly correlates with the regions land degradation, reduced river flow and food-insecurity level.

The key challenges in the UBNB for increased water productivity include poor attention to indigenous rainwater management practices for wide-scaling acceptance of modern soil and water practices, limited experience and knowledge of water management particularly to rainfall partitioning, inadequate policy, human and institutional capacity for IWRM [10]. Farmers lack proper guidance for rain water management and lack of attention to rainwater resource in general.

\section{Conclusions and Recommendations}

Rainfall resource within the UBNB is still untapped resource to produce high food and fulfill downstream water requirements. To manage water resources for food-security targets, the rainfall partitioning knowledge is indispensable. This helps to involve farmers in IWRM process for coordinated and fruitful efforts. Usually, familiarizing rainfall partitioning and different water routes to farmers for proper rainwater management is an entry to food-security and agricultural transformation in the country at large. Hence, if farmers are trained with this new concept, it will be a powerful tool to change developing countries 
using rain-water management as an entry program. The study also found that it is easy to train and demonstrate all routes to farmers using modeling and actual field visit to any of local watersheds.

The challenge is how to enhance the knowledge of farmers and experts in rainwater management. Rainwater management training, if possible, with training centre is required at regional level. Beside, advisory and consultation in this regard is vital to fight poverty in the basin and country at large. To further develop with the study, water-route measurement is required for different rain management practices to quantify water loss and savings.

\section{References}

[1] Solomon, G. G. 2006. "Relating Stream Flow to Forest Cover Change and Community Perception in the Koga Watershed Upper Basin of the Blue Nile.” M.Sc. thesis, Hawassa University, Hawassa, Ethiopia.

[2] Kijne, J. W., Barker, R., and Molden, D. 2003. "Improving Water Productivity in Agriculture: Editors' Overview.” In Water Productivity in Agriculture: Limits and Opportunities for Improvement. UK: CAB International.

[3] Starr, G. C. 2005. “Assessing Temporal Stability and Spatial Variability of Soil Water Patterns with Implications for Precision Water Management.” Agricultural Water Management 72 (3): 223-43.

[4] Tuong, T. P., and Bouman, B. A. M. 2003. "Rice
Production in Water-Scarce Environments.” In Water Productivity in Agriculture: Limits and Opportunities for Improvement, edited by Kijne, J. W., Braker, R., and Molden, D. UK: CAB International.

[5] Smith, M., Fereres, E., and Kassam, A. 2002. Crop Water Productivity under Deficient Water Supply. FAO Project Activity in Support of the Global Water Action Plans.

[6] Naylor, R. L. 2008. "Managing Food Production Systems for Resilience.” In Principles of Natural Resource Stewardship: Resilience-Based Management in a Changing World, edited by Chapin, F. S., Kofinas, G. P., and Folke, C. New York: Springer.

[7] Van der Zaag, P. 2006. Integrated Water Resources Management. Lecture Notes, NESCO-IHE Institute for Water Education, Delft, the Netherlands.

[8] Rockstrom, J., Barron, J., and Fox, P. 2003. "Water Productivity in Rain-Fed Agriculture: Challenges and Opportunities for Smallholder Farmers in Drought-Prone Tropical Agro Ecosystems.” In Water Productivity in Agriculture: Limits and Opportunities for Improvement, edited by Kijne, J. W., Braker, R., and Molden, D. UK: CAB International.

[9] Garrido, A., Willaarts, B. A., and Llamas, M. R., ed.. 2014. Water for Food Security and Well-Being in Latin America and the Caribbean: Social and Environmental Implications for a Globalized Economy. London: Routledge.

[10] Shiferaw, B., Okello, J., and Reddy, V. R. 2009. "Challenges of Adoption and Adaptation of Land and Water Management Options in Smallholder Agriculture: Synthesis of Lessons and Experiences.” In Rain-Fed Agriculture: Unlocking the Potential. London, UK: CAB International, 258-75. 